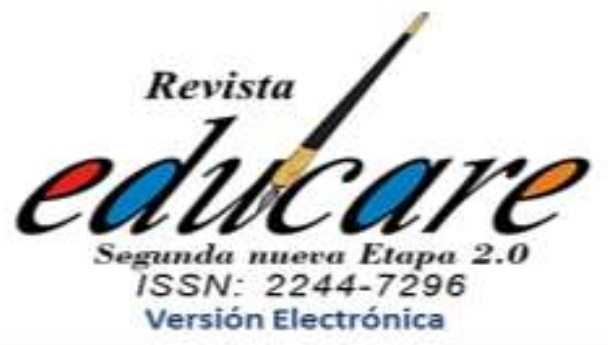

Volumen $25 \mathrm{~N}^{\circ} 1$ Enero - Abril 2021
$(8-29)$

\section{TRAINING PROGRAM ON DEVELOPING READING SKILLS IN THE ENGLISH LANGUAGE AMONG STUDENTS WITH LEARNING DIFFICULTIES}

\section{(Arabia)}

*Assistant Professor, Special Education Department, King Khalid University, Saudi Arabia, mkhasawneh@kku.edu.sa

Recibido:

20-01-2021

Aceptado:

25-03-2021 DESARROLLO DE HABILIDADES DE LECTURA EN INGLÉS PARA ESTUDIANTES CON DIFICULTADES DE APRENDIZAJE

\section{PROGRAMA DE FORMACIÓN PARA EL}



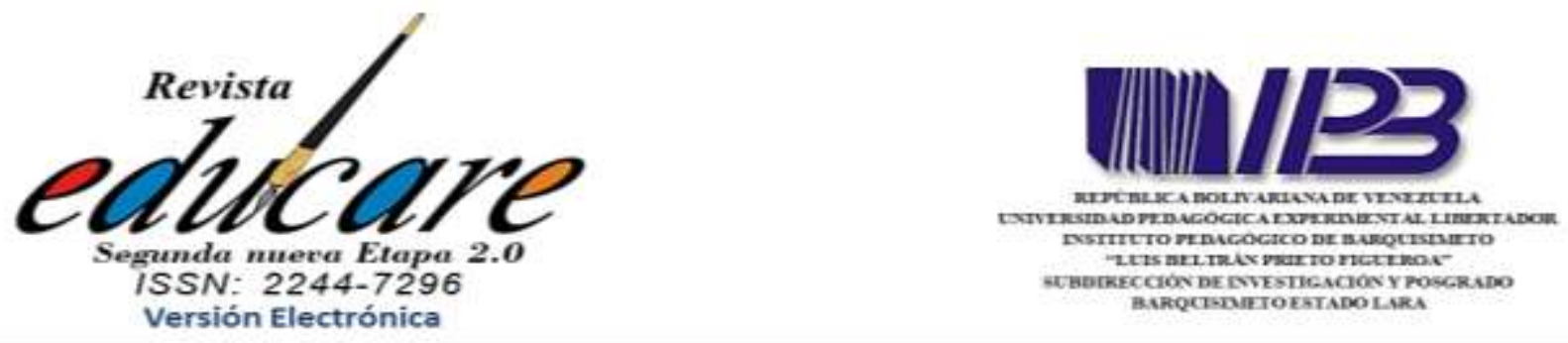

TRAINING PROGRAM ON DEVELOPING READING SKILLS IN THE ENGLISH LANGUAGE AMONG STUDENTS WITH LEARNING DIFFICULTIES

\section{Programa de formación para el desarrollo de habilidades de lectura en inglés para estudiantes con dificultades de aprendizaje}

\section{Abstract}

This study aimed at developing an electronic training program for the development of reading skills among students with reading difficulties in English language at the primary stage in Aseer region. The study used the reading difficulties assessment battery, the achievement test, and the training program in developing reading skills. The study sample included (29) students from the third and fourth grades, who are studying in resources rooms of students with learning difficulties. The ANCOVA analysis was used to analyze the data. The results revealed that the experimental outperformed the control groups in developing reading skills. The results also indicated the absence of significant differences between the experimental and control groups according to gender. Finally, the results also revealed the absence of significant differences between the two groups according to the grade (third/fourth).

Keywords: electronic training program; students with difficulties; dyslexia, primary school.

\section{Resumen}

Este estudio tenía como objetivo desarrollar un programa de formación electrónica para el desarrollo de habilidades de lectura entre los estudiantes con dificultades de lectura en inglés en la etapa primaria en la región de Aseer. El estudio utilizó la batería de evaluación de dificultades de lectura, la prueba de logro y el programa de capacitación en el desarrollo de habilidades de lectura. La muestra de estudio incluyó a (29) estudiantes de tercer y cuarto grado, que están estudiando en salas de recursos de estudiantes con dificultades de aprendizaje. El análisis ancova se utilizó para analizar los datos. Los resultados revelaron que lo experimental superó a los grupos de control en el desarrollo de habilidades de lectura. Los resultados también indicaron la ausencia de diferencias significativas entre los grupos experimentales y de control según el género. Por último, los resultados también revelaron la ausencia de diferencias significativas entre los dos grupos según la nota (tercero/cuarto).

Palabras clave: programa de formación electrónica; estudiantes con dificultades, dislexia, escuela primaria. 


\section{Introduction}

Reading is a very complex cognitive function, as it is the product of the interaction of many mental processes. It includes the interaction of auditory perception, visual perception, attention, memory, and linguistic understanding. Reading is of great importance to psychologists because it helps in identifying the aspects of language processing and helps in informing methods of teaching reading.

Reading is also a continuous interaction between stimuli and memory, which indicates the importance of the role of various cognitive processes in the individual and is useful in organizing the process of interaction of objects in the external environment (Khasawneh, 2020). Reading consists of a set of skills such as the reception skill while writing represents the skill of transmission. These two major skills are part of the language, which is very important in the life of the individual and society, as it allows communication with others in the past and the present and a tool for society to preserve its heritage, culture, and social cohesion (Jaljal, 2016).

When special circumstances occur, distance learning can be activated and students can stop attending schools, as part of precautionary measures. This case happened recently after the outbreak of the COVID-19 pandemic, where schools were closed to achieve physical and social distancing to prevent the spread of the virus early in the year 2020. The first cases were recorded. Covid-19 disease at the end of 2019, the virus was isolated, the genetic makeup was determined, and the World Health Organization was informed about the disease by January 2020.

The virus has spread to several cities in China and many countries in the continents of Asia, America, and Europe. Thus, the World Health Organization announced the state of emergency in the world on 31 January 2020. Although the specifications for considering it a global pandemic were met, the organization did not declare it a global pandemic until 11 March 2020. This delay may have played a role in the spread of the disease in the way that happened (Economic and Social Council, 2020). The shift to online education motivated educational institutions and educators to think of solutions. Hence, researchers conducted 
studies and provided solutions to develop an electronic training program in which students are trained remotely to overcome the conditions created by the COVID-19 pandemic.

\section{Problem statement}

The researcher noticed a large gap in communication between teachers of students with learning difficulties with their students and their families during the Corona pandemic, which imposed the application of distance learning. The researcher also noticed that there is a clear weakness in the effectiveness of applications for electronic educational platforms, in addition to the general weakness in the infrastructure, whether they are in the availability of tools, or the Internet, and the ability and competence of teachers to apply the distance learning process. The resource room teachers face obstacles represented in not being exposed to such a crisis and its repercussions before, and the difficulty of teaching students remotely in such circumstances because of the symptoms this group suffers from, such as problems with attention, concentration, memory, and perception. Therefore, this study attempted to develop an electronic educational program to mitigate the effects of the emerging coronavirus crisis on students. This study aims at achieving the following objectives:

- Identifying the effect of using the training program on developing reading skills in English language for students with reading difficulties (dyslexia) in the primary stage in Aseer region.

- Identifying the effect of the proposed training program in developing reading skills in English for students with reading difficulties according to gender.

- Identifying the effect of the proposed training program in developing reading skills in English for students with reading difficulties according to grade.

The present study seeks to give answers to the following research questions:

- What is the effect of the proposed training program on developing reading skills in English language for students with reading difficulties (dyslexia) in the primary stage in Aseer region?

- Does the effect of the proposed training program in developing reading skills in English for students with reading difficulties differ according to gender?

- Does the effect of the proposed training program in developing reading skills in English for students with reading difficulties differ according to grade? 


\section{Significance of the Study}

The significance of this study stems from its provision of an electronic training program for students with reading difficulties in English language through the multisensory model. The study invites teachers and parents to be free from the prevailing models in education that depend on collecting and preserving information without benefiting from it in practice and also alerting officials in Education to use remedial programs to develop students' skills to enhance their potentials and energies and to make use them in developing their reading skills.

\section{Delimitations of the Study}

This study is limited by the following:

- Time limitations: The study was applied in the first semester of 2021-2022.

- Spatial limitations: The study was applied in schools at the Education Directorate in Aseer region.

- Human limitations: The study was applied to a sample of male and female primary school students (third and fourth grades).

\section{Literature Review}

Reading is a very complex cognitive function that requires the interaction of different mental processes. While reading the auditory perception, visual perception, attention, memory, and linguistic understanding all work together to produce this activity. The importance of reading to psychologists stems from its ability to reflect the individual's capacity to process the language. In education, understanding the reading process helps in designing and developing the optimal teaching methods.

Teaching reading is not an easy task for educators, as it entails good knowledge of the interactive cognitive processes in the individual, which is useful in establishing an organization for the interaction between things in the external environment (Khasawneh, Alkhawaldeh, \& Al-Khasawneh, 2020).

Reading is defined as a mental psychological process that includes the ability to convert written symbols into spoken symbols. Reading is one of the basic psychological processes that require several mental processes necessary for their emergence, and it can be 
classified into three types: reading aloud, silent reading, and reading comprehension, which is the natural sequence of student reading skills (Alkhawaldeh, khasawneh, \& Al-qahtani, 2017).

The purpose of reading any material is to understand its content and convert symbols into meanings. Understanding itself is a problem that extends beyond the mere process of decoding symbols to find their equivalents. Reading comprehension is interpreted as being part of the developmental hierarchy of language arts (listening, speaking, reading, and writing) which requires an understanding of written symbols (khasawneh, 2016).

Reading difficulties mean the failure to achieve the intended goals of reading, such as the failure to understand the written text, or perception of the relationships between meanings and ideas or their expression, or slowness in pronouncing, or defective pronunciation or incorrect pronunciation of the words (Radwan \& Al-Jamal, 2014).

\section{Previous Studies}

Herburger (2020) identified instructions and resources to help teachers support students with disabilities in the distance learning process caused by the Covid-19 pandemic. The study sample consisted of teachers of students with disabilities in some schools of the United States of America. The results of the study showed that many of the educational structures and support for students with disabilities that were present in the regular classroom are different in the distance learning environment because students with disabilities have a group of needs. The results showed that teachers need to think about the best ways to meet the individual needs of each student. The results also showed that students with disabilities face many challenges as a result of distance learning, such as their inability to learn in faceto-face sessions with teachers.

Distance learning enhanced low self-concept and raised the level of self-confidence among students with disabilities. Distance learning has also increased teachers' new teaching skills, multiple ways of providing meaningful interactions between teacher and students, providing new tools to make distance learning available to all students, and ways to provide feedback through resource rooms.

Riemers, Schleicher, Saavedra, and Tuominen (2020) identified ways to continue learning during the Covid-19 pandemic, while school enrollment was not possible. Given students' ability to access digital devices and the Internet, governments have supported education 
systems to create effective forms of online education, which freed up institutional capacities and resources to reorient their focus on offering students alternative learning methods. The study sample was selected from (333) participants in (99) countries.

The study identified tools that can help in managing education and learning and other tools that teachers, parents, or students can use to create or access educational content. The study dealt with some of the aspects that will focus on during distance learning (processing and cognitive strategies, knowledge, creativity, and innovation, cooperative group skills, leadership, intellectual openness, work ethics and responsibility, self-efficacy). This all was to communicate information to all students who participate in the process of distance learning.

Williams and Vaughn (2020) examined the impact of applying a reading intervention, called the Reading Intervention for Adolescents, on reading outcomes (vocabulary, comprehension, and word reading) for $9^{\text {th }}$ grade English Language students with learning disabilities. The study sample consisted of four random groups of 10 to 15 students from three diverse highs-schools in the southwestern U.S, from which two distinct groups (comparison and treatment) were created to analyze the treatment effects. An analysis of covariance was used to test for treatment effects and control for false discovery rate. The results showed the absence of significant differences in the students' scores on the posttest in reading outcomes. The only outcome that was affected was proximal vocabulary. However, students performed better after receiving the treatment in comparison to their previous levels.

Ihbour, Hnini, Anarghou, Ahami, Chigr, and Najimi (2019) examined and analyzed the social and cognitive variables related to various reading skills among students in primary and secondary public schools in Morocco. The sample of the study consisted of 754 students (388 boys and 366 girls) aged between 9 to 15 years old. The diagnostic tests identified 481 students as good readers, 128 intermediate level, 145 as bad readers, using 12 tests to evaluate the students. Data was collected by using a fact sheet, including data on economical and socio-cultural characteristics. The results of the study showed that learning-to-read difficulties are particularly frequent in non-favorable socio-cultural environments. It also showed that phonological awareness and rapid naming are the most implicated factors in the disparity of reading skills. 
Robinson, Meisinger, and Joyner (2019) examined the effects of reading models (silent vs. oral) on reading comprehension among students of primary stage, who have learning disability in reading. The study used the ANOVA analysis to analyze data. The study sample consisted of 77 students from a second, third, fourth, and ninth grade from a school in America that provides day treatment program for students with dyslexia. The parental consent was acquired to participate in the study. Data were collected during the school year of 2015-2016 and the year of 2016-2017. The results of this study showed that reading modality helped in identifying students' weakness and in designing the appropriate measures to treat reading comprehension problems.

Shamir and Maor (2019) investigated the effect of an educational e-book on vocabulary acquisition among students with intellectual disability (ID). The sample of this study consisted of 30 students ( $46.7 \%$ boys and $53.3 \%$ girls), half of them were identified by the Ministry of Education's Psychological Services as students with intellectual disability who were enrolled in the $2^{\text {nd }}$-grade classes at a regular elementary school-aged between 14 to 17 years old. The other half were identified as mild intellectual disabilities who were studying in a special education school, aged between 6.5 to 8 years old. For vocabulary, students were asked to give the meaning of 10 different words that have been taken from a story's text. As for the reading abilities, the measurement tool was based on the Individual Word Reading Test constructed by Shani, Lachman, Shalem, Bahat, and Zeiger (2003). This study showed that students with either learning disabilities or intellectual disabilities significantly improved their vocabulary after five rereading sessions with the specially designed e-book.

Weiser, Buss, Sheils, Gallegos, and Murray, (2019) investigated the effectiveness of technology-based coaching for special education 8th-grade students experiencing reading learning disabilities. The study used a technology-based coaching, or on-demand coaching (teachers could request support if needed). The study sample consisted of 452 special educations 8th grades students experiencing reading learning disabilities, a quasiexperimental was designed to investigate the literacy outcomes. The results of this study found the effectiveness of the three methods of coaching. However, coaching by using technology proved to be more effective, reducing time and resourceful for teachers. 


\section{Research Methodology}

\section{Population and Sample}

The study population consisted of (300) students diagnosed with reading difficulties in English language. The study sample consisted of (29) students who were randomly assigned to an experimental group and a control group.

\section{Research Instrument}

The study used the following instruments:

\section{- First: John Raven's sequential matrices test:}

The test consisted of (48) matrices ranging in difficulty from mere accuracy of observation until reaching measuring the perception of relationships of higher mental aspects that involve abstraction. It was found that the correlation coefficients between the test and the verbal tests were high (Odeh and Suleiman, 2013).

The validity of the test was calculated by extracting the correlation coefficient between the sequential matrix test and the academic achievement of students. The results showed that there is a positive correlation of (0.61).

\section{- Second: Dyslexia tests}

The battery of tests for diagnosing dyslexia is concerned with diagnosing weaknesses, deficiencies, and errors through the student's treatment of a specific topic. It does not depend in its judgment on the total score obtained by the student as much as it looks at the errors and difficulties that this student is facing. It shows us where the strengths of a student's performance lie.

The validity of the test was verified by presenting the test battery to a group of specialists in the fields of English language and special education to evaluate these tests. The researcher changed, modified, and deleted the phrases referred to by the judges.

The reliability of the battery tests that measure reading difficulties (dyslexia) was calculated by a re-test method using the Pearson correlation coefficient as shown in Table (1). 
Table (1): Pearson correlation coefficients for dyslexia tests battery

\begin{tabular}{|c|c|c|c|c|}
\hline \multirow{2}{*}{ Tests } & \multicolumn{2}{|c|}{ Third } & \multicolumn{2}{|c|}{ Fourth } \\
\hline & Males & Females & Males & Females \\
\hline Accuracy & $* * 0.77$ & $* * 0.78$ & $* * 0.78$ & $* * 0.83$ \\
\hline Reading test & $* * 0.66$ & $* * 0.70$ & $* * 0.85$ & $* * 0.88$ \\
\hline Comprehension & $* * 0.67$ & $* * 0.71$ & $* * 0.76$ & $* * 0.80$ \\
\hline Spelling test & $* * 0.69$ & $* * 0.72$ & $* * 0.65$ & $* * 0.67$ \\
\hline Visual processing test & $* * 0.86$ & $* * 0.78$ & $* * 0.74$ & $* * 0.79$ \\
\hline Phonological awareness test & $* * 0.80$ & $* * 0.86$ & $* * 0.77$ & $* * 0.92$ \\
\hline $\begin{array}{l}\text { Test of remembering words in } \\
\text { reverse }\end{array}$ & $* * 0.65$ & $* * 0.66$ & $* * 0.68$ & $* * 0.70$ \\
\hline
\end{tabular}

**Significant at.(0.01)

It is noted from the previous table that Pearson's correlations have a high degree of stability, and they measure the goal for which they were set.

\section{- Fourth: the achievement test}

The researcher designed the achievement test for students with reading difficulties (dyslexia) to measure the effectiveness of the training program. After reviewing the books prescribed for the elementary stage, the researcher prepared this test to suit and fit students in the third and fourth grades, who suffer from reading difficulties (dyslexia).

The researcher conducted a survey of teachers' opinions, where their opinions were taken on the suitability of this test in terms of its content and vocabulary for third and fourth grades, and the order of skills from ease to difficulty and their suitability for pupils.

The researcher calculated the stability of the test by the Test-Retest method. The test was applied twice with an interval of two weeks on an exploratory sample of students of the third and fourth grades. The correlation coefficient between the first and second applications was (0.78), which is significant at (0.01), which means that the test with its components has demonstrated an adequate level of stability that can be relied upon.

\section{- Fifth: The proposed training program}

After reviewing several training programs in reading development in educational literature, the researcher prepared a proposed training program for students with reading 
difficulties in English language (dyslexia). Students were first diagnosed and identified, and then the program was implemented to develop their reading skills.

\section{Findings and Discussion}

First: Results related to the differences between the two groups (experimental / control) after implementing the training program:

The study extracted the mean scores and standard deviations for the scores of the two groups (experimental/control) in the posttest. The results of the analysis are shown in Table (2)

Table (2): The mean scores and standard deviations of the students' results in the posttest

\begin{tabular}{ccccc}
\hline Test & Group & NO. & Mean score & $\begin{array}{c}\text { Standard } \\
\text { deviation }\end{array}$ \\
\hline \multirow{2}{*}{ Post achievement test } & Experimental & 14 & 28.93 & 2.7 \\
& Control & 15 & 19.64 & 1.7 \\
\hline
\end{tabular}

The results shown in the previous table indicate the difference in the mean scores in the posttest for the two groups (experimental / control). The mean score for the experimental group to which the program was applied was higher than the mean score of the control group. To examine the significance of the differences in these scores, ANCOVA was used, and Table (3) shows these results.

Table (3): Results of ANCOVA analysis to examine the effect of the program in the post-achievement test

\begin{tabular}{ccccccc}
\hline \multirow{2}{*}{ Variable } & $\begin{array}{c}\text { Source of } \\
\text { variance }\end{array}$ & $\begin{array}{c}\text { Sum of } \\
\text { square }\end{array}$ & $\begin{array}{c}\text { Freedom } \\
\text { value }\end{array}$ & $\begin{array}{c}\text { Mean } \\
\text { square }\end{array}$ & F value & Sig. \\
\cline { 2 - 7 } & Interaction & 15.237 & 1 & 15.237 & 3.769 & 0.063 \\
\multirow{2}{*}{ achievement } & Post-test & 43.44 & 1 & 43.44 & 10.648 & 0.03 \\
& Group & 651.462 & 1 & 651.462 & 161.156 & 0.000 \\
& Error & 105.103 & 26 & 4.042 & & \\
\hline
\end{tabular}


The results of the ANCOVA analysis indicate that there are statistically significant differences at $\mathrm{t}(\alpha=0.05)$ in the performance of the experimental and control groups in the total score of the achievement test attributable to the program. The F value was (161.156). The mean score of the experimental group was (28.93), while the mean score of the control group was (19.64), and these differences are in favor of the experimental group. These results indicate that the experimental group surpassed the control group in the post-test. This result confirms that the training program has succeeded in developing reading skills for students with reading difficulties (dyslexia), as the two groups were equal before implementing the program, then the experimental group outperformed the control group after implementing the program.

Second: The results related to the differences in the performance of the students after implementing the program according to the difference in gender

The study extracted the mean scores and standard deviations for the scores of students according to gender in the posttest, as shown in Table (4).

Table (4): The mean scores and standard deviations of the post-test for the experimental group

\begin{tabular}{ccccc}
\hline Test & Group & NO. & Mean score & $\begin{array}{c}\text { Standard } \\
\text { deviation }\end{array}$ \\
\hline \multirow{2}{*}{ Experimental } & Males & 10 & 28.30 & 2.750 \\
group & Females & 5 & 30.20 & 2.789 \\
& Total & 15 & 28.933 & 2.789 \\
\hline
\end{tabular}

These results indicate the difference in the mean scores in the post-achievement test for the experimental group (males/females). It is noticed that the mean scores of females in the posttest were higher than the mean scores of the males. To determine the significance of the differences in these scores, the ANCOVA analysis was used, as shown in Table (5). 
Table (5): ANCOVA analysis to examine the effect of the program on the experimental group (males/females)

\begin{tabular}{ccccccc}
\hline Variable & $\begin{array}{c}\text { Source of } \\
\text { variance }\end{array}$ & $\begin{array}{c}\text { Sum of } \\
\text { square }\end{array}$ & $\begin{array}{c}\text { Freedom } \\
\text { value }\end{array}$ & $\begin{array}{c}\text { Mean } \\
\text { square }\end{array}$ & F value & Sig. \\
\hline \multirow{6}{*}{ Experimental } & Interaction & 8.407 & 1 & 18.407 & 2.854 & 0.117 \\
group & Post-test & 19.516 & 1 & 19.516 & 3.026 & 0.107 \\
& Group & 14.309 & 1 & 14.309 & 2.219 & 0.162 \\
& Error & 77.384 & 12 & 6.449 & & \\
& Total & 12666.00 & 15 & & & \\
\hline
\end{tabular}

The results of the ANCOVA analysis indicate that there is no statistically significant effect of the training program based on gender. The F-value was (2.219), which was not statistically significant. This result confirms that the experimental group members did not have differences according to gender (male/female).

Third: The results related to the differences between the experimental group students after implementing the program according to the grade (third/fourth).

The study extracted the mean scores and standard deviations for the scores of students according to grade in the posttest, as shown in Table (6).

Table (6): The mean scores and standard deviations of the post-test for the experimental group according to grade (third/fourth)

\begin{tabular}{ccccc}
\hline Group & Grade & NO. & Mean score & $\begin{array}{c}\text { Standard } \\
\text { deviation }\end{array}$ \\
\hline $\begin{array}{c}\text { Experimental } \\
\text { group }\end{array}$ & Fourd & 8 & 28.625 & 2.875 \\
& Total & 7 & 29.285 & 2.870 \\
& 15 & 28.933 & 2.789 \\
\hline
\end{tabular}


The results of Table (6) refer to the convergence of the mean scores in the post-test of the experimental group students for the two (third/fourth) grades. To examine whether this convergence is statistically significant, the ANCOVA analysis was used, as shown in Table (7).

Table (7): the results of the ANCOVA analysis to examine the effect of the program on the experimental group according to grade (third/fourth)

\begin{tabular}{|c|c|c|c|c|c|c|}
\hline Variable & $\begin{array}{l}\text { Source of } \\
\text { variance }\end{array}$ & $\begin{array}{l}\text { Sum of } \\
\text { square }\end{array}$ & $\begin{array}{c}\text { Freedom } \\
\text { value }\end{array}$ & $\begin{array}{c}\text { Mean } \\
\text { square }\end{array}$ & F value & Sig. \\
\hline \multirow{5}{*}{$\begin{array}{c}\text { Experimental } \\
\text { group }\end{array}$} & Interaction & 11.363 & 1 & 11.363 & 1.502 & 0.244 \\
\hline & Post-test & 16.508 & 1 & 16.508 & 2.182 & 0.165 \\
\hline & grade & 0.897 & 1 & 0.897 & 0.119 & 0.737 \\
\hline & Error & 90.795 & 12 & 7.566 & & \\
\hline & Total & 12666.000 & 15 & & & \\
\hline
\end{tabular}

Table (7) indicates that there is no statistically significant effect of the training program. The F-value was (0.119), which is not statistically significant. This result confirms that the members of the experimental group had no differences between them according to grade (third/fourth) after implementing the training program.

All previous results indicate that the experimental group and the control group were equal before implementing the program, and after implementing the training program, the following results were shown:

- The experimental group surpassed the control group in the total score of the postachievement test after implementing the program.

- There are no statistically significant differences between the members of the experimental group according to gender (male/female) after implementing the program.

- There are no statistically significant differences between the members of the experimental group according to grade (third/fourth) after implementing the program.

- The experimental group showed a greater improvement than the control group in the post-test. This improvement is due to the performance of the experimental group in the 
achievement test for using the (training) program in this study. The training program has proven that it has helped a great deal in developing reading skills, through the presence of statistically significant differences in favor of the experimental group. This improvement was due to the content of the training program on reading skills. It can be said that the strategies and mechanisms of focusing on the multisensory method indirectly helped to develop the required skills.

The findings can be interpreted in light of the components of the program and the effort made in the research experience, as well as the length of time that the program implementation period took. Perhaps the program helped, and the effort made with students during the two-month to overcome students' problems with reading difficulties (dyslexia).

The most important finding of this study is the experimental group outperformed the control groups. This indicates that the training and treatment were beneficial and thus consistent with all the literature dealing with reading difficulties (dyslexia). The program provided a good opportunity for improvement, especially if these programs used interesting experiments. Students felt the benefit and enjoyment throughout the implementation of the training program, in addition to the immediate feedback that prompts students to make every effort and activity through experimental work.

Previous studies that relied on the experimental approach, provided similar results. This means that when the appropriate opportunity is available for students and a good teacher and qualified in special education to provide the appropriate treatment, good results will appear. The students reading skills improved appropriately, and this is what we lack in our regular schools in general. However, there are difficulties in learning to read for many primary school students.

The reason for this is curricula and courses that lack educational methods that suit the needs of these students, as well as because they lack a teacher who provides the appropriate educational atmosphere for these students. The teacher needs special preparation in teaching methods for students with reading difficulties (dyslexia).

\section{Recommendations}

The study recommends the following:

1. Conducting a study similar to the current one targeting students with other learning difficulties, such as mathematics difficulties and writing difficulties in the elementary level. 
2. Conducting a study similar to the current one, targeting a sample of males and females with reading difficulties (dyslexia) at the primary stage.

3. The study recommends designing similar programs to the current program, which is based on a (multi-sensory) model in other learning difficulties, such as mathematics difficulties and writing difficulties. The results of the current study demonstrated the effectiveness of the program in developing reading skills for students with reading difficulties (dyslexia).

\section{Acknowledgments}

The authors extend their appreciation to the Deanship of Scientific Research at King Khalid University for funding this work through Small Research Groups under grant number (RGP.1 140/42)

\section{References}

Abdul Raouf, F. (2017). Sequential Matrix Test, Instruction Sheet. Kuwait: Ministry of Education.

Alkhawaldeh, M khasawneh, M and Al-qahtani, T .(2017). Learning to See Reciprocal Teaching Approach in New Ways: Foundation for Minting Cognitive Demand. Journal of Education Sohag University. (50), pp.(293- 312).

Odeh, A S \& Omar, S. (2013). Adaptive informing efficacy calculated in the Mental Capacity Report using Raven matrices. Dirasat: Educational Sciences, 40 (2)

Economic and Social Council. (2020). Response plan to the repercussions of the new Corona virus on the country, Amman, Jordan.

Jeljel, N. (2016). Reading difficulties (dyslexia). Amman. Dar Al Fikr Publishers and Distributors.

Khasawneh, M. A. S.(2020). The Level of Metacognitive Thinking among Students with Learning Disabilities. International Journal of English Linguistics, Education. Vol. 10, No. 5.

Khasawaneh, M., \& Arabia, S. (2016). The Impact of a Training Program Based on the Visual Words Composition Techniques on the Development of Reading Comprehension Skills among the Students of Primary Stage. Advances in Bioresearch, 7(2). 
https://www.researchgate.net/publication/329091984_International_Journal_of_Aca demic Research

Khasawneh, M. A. S, Alkhawaldeh, M \& Al-Khasawneh, F.S.(2020). The Level of Metacognitive Thinking Among Students with Learning Disabilities. International Journal of English Linguistics; Vol. 10, No. 5. doi:10.5539/ijel.v10n5p343 URL: https://doi.org/10.5539/ijel.v10n5p343

Herburger, D. (2020) Considerations for Teachers Providing Distance Learning to Students with Disabilities, WestEd.org, Crisis Response Resource, Department of Education, Office for Civil Rights, U.S.

Ihbour, S., Hnini, R., Anarghou, H., Ahami, A. T., Chigr, F., \& Najimi, M. (2019).

Diagnosis Of Dyslexic Disorders And Identification Of Factors Associated With Reading Learning Disabilities Within The Moroccan Context. Acta Neuropsychologica, 17(3).

Riemers, F.; Schleicher, A.; Saavedra, J. \& Tuominen, S. (2020). Supporting the continuation of teaching and learning during the COVID-19 Pandemic Annotated resources for online learning, OECD Better Policies for Better Lives, www.oecd.org/education

Radwan, M and Al-Jamal, M. (2014). Arabic language and its skills at university level for non-specialists. Al-Ain: University Book House.

Robinson, M. F., Meisinger, E. B., \& Joyner, R. E. (2019). The influence of oral versus silent reading on reading comprehension in students with reading disabilities. Learning Disability Quarterly, 42(2), 105-116.

Shamir, A., \& Maor, R. (2019). E-Books for promoting vocabulary among students with intellectual disability as opposed to children with learning disability: Can repeated reading make a difference?. Journal of Cognitive Education and Psychology, 17(2), 164-177.

Weiser, B., Buss, C., Sheils, A. P., Gallegos, E., \& Murray, L. R. (2019). Expert reading coaching via technology: Investigating the reading, writing, and spelling outcomes of students in grades $\mathrm{K}-8$ experiencing significant reading learning disabilities. Annals of dyslexia, 69(1), 54-79. 
Williams, K. J., \& Vaughn, S. (2020). Effects of an Intensive Reading Intervention for Ninth-Grade English Learners With Learning Disabilities. Learning Disability Quarterly, 43(3), 154-166. 